Arq. Bras. Med. Vet. Zootec., v.67, n.1, p.265-273, 2015

\title{
Integrated multi-trophic culture of Nile tilapia (Oreochromis niloticus) and Amazon river prawn (Macrobrachium amazonicum) in brackish water
}

\author{
[Cultivo multi-trófico integrado de tilápia-do-nilo (Oreochromis niloticus) e camarão da \\ Amazônia (Macrobrachium amazonicum) em água salobra] \\ G.G. Henry-Silva ${ }^{1}$, C.S.P. Maia1, R.S.T. Moura ${ }^{1}$, A.P. Bessa Junior ${ }^{1}$, W.C. Valenti ${ }^{2}$ \\ ${ }^{1}$ Universidade Federal Rural do Semi-árido -UFERSA - Mossoró, RN \\ ${ }^{2}$ Universidade Estadual de São Paulo - UNESP - Campus de São Vicente - São Paulo, SP
}

\begin{abstract}
The aim of this study was to assess the feasibility of integrated multi-trophic culture of Nile tilapia (Oreochromis niloticus) and Amazon River prawn (Macrobrachium amazonicum) in brackish water by evaluating its limnological characteristics and economic performance. The experiment was completely randomized with four treatments and four repetitions: control treatment with Nile tilapia only, stocked with 2 tilapias $/ \mathrm{m}^{2}(\mathrm{P} 2 \mathrm{C} 0)$ and three integrated multi-trophic culture treatments stocked with 2 tilapias $/ \mathrm{m}^{2}$ and prawns at densities of 4, 8 and 16 prawns $/ \mathrm{m}^{2}$ (P2C04, $\mathrm{P} 2 \mathrm{C} 08$ and $\mathrm{P} 2 \mathrm{C} 16$, respectively). The limnological variables of temperature, $\mathrm{pH}$, dissolved oxygen, turbidity, ammonia, orthophosphate and chlorophyll "a" were evaluated and throughout the experiment remained within the limits recommended for culture. The experiment lasted 150 days with monthly animal sampling. No significant differences were observed for total fish biomass or for fish and prawn total survival rates. However, prawn individual weight decreased as stocking density increased. Gross revenue was not significantly different between treatments, as well as profitability. The profitability was $40.1 \%$ (P2C0), 36.7\% (P2C04), 41.2\% (P2C08) and $50.1 \%$ (P2C16). It is concluded that although feasible from the view point of husbandry, the integrated multi-tropic culture of $M$. amazonicum and $\mathrm{O}$. niloticus did not influence significantly profitability compared to the monoculture system.
\end{abstract}

Keywords: aquaculture, sustainability, polyculture

\section{RESUMO}

O objetivo deste estudo foi verificar a viabilidade do cultivo multitrófico integrado da tilápia-do-nilo (Oreochromis niloticus) e do camarão-da-amazônia (Macrobrachium amazonicum) em água salobra, mediante a avaliação de suas características limnológicas e de seu desempenho econômico. $O$ experimento foi inteiramente ao acaso, com quatro tratamentos e quatro repetições: tratamento controle somente com tilápia-do-nilo, estocado com duas tilápias $/ m^{2}(P 2 C 0)$ e três tratamentos de cultivo multitrófico integrado, estocados com duas tilapias $/ m^{2}$ e camarões nas densidades de quatro, oito e 16 camarões $/ m^{2}$ (P2C04, P2C08 e P2C16, respectivamente). As variáveis limnológicas temperatura, pH, oxigênio dissolvido, turbidez, amônia, ortofosfato e clorofila " " "foram avaliadas e, durante todo o experimento, mantiveram-se dentro dos limites recomendados para o cultivo. O experimento durou 150 dias, com amostragem mensal dos animais. Diferenças significativas não foram observadas para a biomassa total de peixe nem para a taxa de sobrevivência total em peixes e camarões. Entretanto, o peso individual do camarão diminuiu à medida que a densidade de estocagem aumentou. A receita bruta não foi significativamente diferente entre os tratamentos, assim como a rentabilidade. A rentabilidade foi 40,1\% (P2C0), 36,7\% (P2C04), 41,2\% (P2C08) e 50,1\% (P2C16). Conclui-se que, apesar de viável do ponto de vista da larvicultura, o cultivo multitrófico integrado de M. amazonicum $e$ O. niloticus não influenciou significativamente a rentabilidade quando comparado com o sistema de monocultura.

Palavras-chave: aquicultura, sustentabilidade, policultivo

Recebido em 22 de abril de 2013

Aceito em 19 de fevereiro de 2014

E-mail: gustavo@ufersa.edu.br 


\section{INTRODUCTION}

The commitment to pursue aquaculture practices that live up to the sustainability concept is of utmost importance today. This concept, among many other things, encourages the implementation of multi-trophic culture systems using the native species. In this context, the aquaculture business people should develop their activities guided by the sustainability concept, since a production system that takes into account only the financial opportunities and the market is not sustainable over time (Boyd, 2003).

The integrated multi-trophic aquaculture is characterized by cultivating two or more species of aquatic organisms of different trophic levels in a single productive unit, this system could, therefore, be a viable alternative to make aquaculture more profitable and sustainable (Zimmermann and New, 2000; Chopin et al., 2001; Muangkeow et al., 2007). This system aims at optimizing the use of existing food in the pond, without increasing feed competition between species. The multi-trophic system uses species with different feeding and habitat requirements, in order to maximize production through efficient occupation of physical space and different ecological niches (Cohen and Ra'anan, 1983; Wohlfarth et al., 1985; Lutz, 2003; Milstein et al., 2006).

In multi-trophic systems new food sources can be harnessed, in addition to a synergism that may occur between species, which would tend to perform better together than in monoculture (Lutz, 2003). The multi-trophic and polyculture systems may generate less organic matter and nutrient inputs in the nearby aquatic environments and can ultimately increase producer revenue through the sale of two or more species that are well accepted in the market (McGinty and Alston, 1987).

Nile tilapia (Oreochromis niloticus) displays the appropriate characteristics and wide availability of fingerlings for use in multi-trophic systems. This species is quite rough, with diverse feeding habits, feeds well on ration, has excellent quality meat and is widely cultivated in Brazil. The Amazon River prawn (Macrobrachium amazonicum) has a relatively well spread production system, from post-larvae production and maturation to grow-out phase, and great potential for aquaculture (Kutty et al., 2000; Kutty, 2005; New, 2005). Although it is a small shrimp that reaches up to $16 \mathrm{~cm}$ and average weight $30 \mathrm{~g}$, its meat has firmer texture and stronger flavor compared to $M$. rosenbergii (Moraes-Riodades and Valenti, 2001).

M. amazonicum is widely consumed in the Amazon and Northeast Brazil and is commonly found in South America (Bialetzki et al., 1997; Kutty et al., 2000; Moraes-Valenti et al., 2010). M. amazonicum was introduced in northeastern Brazil in the 1940s in a number of ponds as food for carnivorous fish species. Due to its rapid adaptation and high reproductive rate, this species is currently considered an important fishery resource for the region (Sampaio et al., 2007). It is important to note that since 2001, multidisciplinary research being conducted by several research institutions has been developing technology for the cultivation of M. amazonicum in Brazil (Araujo and Valenti, 2007). However, until now there are no studies on the feasibility of $M$. amazonicum culture in a multi-trophic system.

Therefore, the aim of this study was to assess the feasibility of an integrated multi-trophic system of Nile tilapia (O. niloticus) and Amazon River prawn (M. amazonicum) in brackish water, by evaluating the limnological parameters, husbandry development and economic feasibility of a culture with both species.

\section{MATERIAL AND METHODS}

The experiment was conducted at the Aquaculture Division of the Universidade Federal Rural do Semi-Árido - UFERSA, in Mossoró, RN, located at $05^{\circ} 11^{\prime}$ S Latitude, $037^{\circ} 20^{\prime} \mathrm{W}$ Longitude and $18 \mathrm{~m}$ altitude. The experiment lasted 150 days, from the end of the dry season and beginning of rainfall of year 2011. The ponds were first stocked with the prawns and 15 days later with the fish. The experimental units consisted of 16 brick ponds (earth bottom), each with $15 \mathrm{~m}^{2}$ area. Each pond underwent a previous insolation period followed by lime application at the rate of $500 \mathrm{~kg} / \mathrm{ha}$ to neutralize $\mathrm{pH}$ or minimize soil acidity due to the organic load generated by previous cultures. The experimental units were supplied with water from a tube well with salinity of $2 \mathrm{~g} / \mathrm{L}$. The water was utilized directly from the well, without salt 
addition or dilution, yet without previous treatment. After filling, the ponds were initially fertilized with calcium nitrate as nitrogen source at a rate of $30 \mathrm{~kg} / \mathrm{ha}$.

The experimental design was completely randomized, with four treatments and four repetitions. The control treatment consisted of a monoculture of Nile tilapia (2 tilapias $/ \mathrm{m}^{2}-$ $\mathrm{P} 2 \mathrm{C} 0$ ), the other three treatments were multitrophic cultures where tilapia density remained constant ( 2 tilapias $/ \mathrm{m}^{2}$ ) while prawn was stocked at the following densities: 4 individuals $/ \mathrm{m}^{2}$ (P2C04), 8 individuals $/ \mathrm{m}^{2}(\mathrm{P} 2 \mathrm{C} 08)$ and 16 individuals $/ \mathrm{m}^{2}$ (P2C16).

Food supply was based on the nutritional requirements of fish, so that the prawns fed on the leftover feed, fish feed water and natural food. Feed consisted of extruded $2 \mathrm{~mm}$ pellets containing $36 \%$ crude protein during the first 30 days, followed by $4 \mathrm{~mm}$ pellet diet with $32 \% \mathrm{CP}$ up to 60 days, and finally a $6 \mathrm{~mm}$ ration with $32 \%$ CP until the end of cultivation, offered four times per day based on the percentage of animal biomass calculated by the monthly sampling and daily observation of leftovers. To acquaint, the percentage offered in the first month was $8 \%$, followed by $6 \%$ in the second month, $4 \%$ in the third, $3 \%$ in the fourth and $2.5 \%$ in the fifth month.

The limnological variables of temperature, dissolved oxygen, $\mathrm{pH}$ and turbidity were measured monthly using a water quality multisensor (HORIBA model U-50G). Monthly water samples were obtained to determine the concentrations of $\mathrm{N}$-ammoniacal (Mackereth et al., 1978), P-orthophosphate (Golterman et al., 1978) and chlorophyll "a" (Arar, 1997).

Samplings of fish and prawns were conducted monthly using cast nets with meshes between 8 and $10 \mathrm{~mm}$ and trawl with mesh of $2 \mathrm{~mm}$, respectively. Husbandry parameters were determined for samples that contained $10 \%$ of the animals in the experimental unit. Mean individual mass/weight is given by dividing the sampled biomass by the total number of individuals, while the mean final weight gain is given by dividing the total final biomass by the number of surviving individuals. The survival rate, as a percentage, is given by the number of harvested animals divided by the number of stocked animals multiplied by 100 . The production is given by the biomass of all harvested animals $(\mathrm{kg})$ extrapolated to the 1 ha area. Apparent Feed Conversion (AFC) is given by the difference between final and initial biomass of fish and prawns divided by the total feed offered.

Cost analysis was performed at the end of the production cycle. The prices paid for inputs and raw materials were given by the producers and traders of these products. The market prices for commercialization of fish and prawn were the prices practiced by producers and merchants that commercialize their productions in Rio Grande do Norte and Ceará states. These prices were calculated based on individual weight. The type of cost analysis in this study corresponds to total expenditures (total cost) per hectare of cultivated area, thus covering fixed and variable costs.

Total Operating Cost (CTop) is given by the sum of the Variable Operating Cost (CVop) such as fingerlings, post-larvae, feed, fertilizer, alkalizing and sterilants among others and Fixed Operating Cost (CFop) such as power, labor, charges and taxes, consumables/supplies, machinery and equipment, fuel and lubricants, maintenance and depreciation. In the present study, the costs were calculated for a 6 month cycle distributed as follows: a 5 month period for animal grow-out and a 30 day period for preparing the area for a new cultivation cycle. The economic study considered the Gross Revenue (RB) as the production per hectare at prices paid to the producer in the region in 2011 ; Operating Profit (Lop), as the difference between Gross Revenue (RB) per hectare and Total Operating Cost (CTop); and Economic Performance (R\%), as the Operating Profit (Lop) divided by the Total Operating Cost (CTop).

The tests of D'Agostinho and Bartlett were used to test the normality and homogeneity of the data regarding growth, final biomass/weight, survival rate, Apparent Feed Conversion (FC) and economic analysis, respectively. The variables that presented normal distribution and homogeneous variance were analyzed by ANOVA one-way, followed by Tukey test to compare the means among treatments $(\mathrm{P}<0.05)$. 


\section{RESULTS AND DISCUSSION}

Significant differences were observed only over time for all variables, except for orthophosphate and $\mathrm{pH}$. For the variable Temperature no significant differences were observed among treatments, although differences were observed over time, since the experiment was carried out during the end of the dry season and beginning of rainfall in the semiarid region of northeastern Brazil. The temperature of the water in the ponds varied between 27.4 and 29.2 C (Fig. 1a), within the range recommended for Nile tilapia and prawn cultures (New et al., 2010). Dissolved oxygen concentrations were close to the values considered ideal for fish $(5 \mathrm{mg} / \mathrm{L})$ and prawn $(3.5 \mathrm{mg} / \mathrm{L})$ farming (Boyd, 1990) and did not vary significantly among treatments (Fig. 1b). Possibly the fluctuations in Dissolved oxygen levels were mostly due to increased oxygen demand caused by the increasing animal biomass and decomposition rates of organic matter.

Water $\mathrm{pH}$ varied between 7.8 and 8.6 during the experiment (Fig. 1c). For both studied species, as well as most freshwater animals, $\mathrm{pH}$ tolerance ranges from 6.5 to 9.0 (Boyd, 1990; Boyd and Tucker, 1998), while to promote fish growth, the optimum $\mathrm{pH}$ ranges from 7.0 to 8.5 and satisfactory from 8 to 9 (Boyd, 1998). For prawns, the ideal $\mathrm{pH}$ ranges from 7.0 to 8.5 . Therefore, the $\mathrm{pH}$ values obtained in this study were within the recommended range for $O$. niloticus and M. amazonicum cultivation.

Chlorophyll "a" did not change significantly among treatments $(p=0.59)$. From the third month, this variable increased for all treatments, and only in the fifth month, the P2C0 treatment (monoculture) displayed lower values $(183.63 \pm 149.4 \mu \mathrm{g} / \mathrm{L}) \quad$ compared to $\mathrm{P} 2 \mathrm{C} 04$ $(356.50 \pm 303.3 \mu \mathrm{g} / \mathrm{L}), \mathrm{P} 2 \mathrm{C} 08(234.75 \pm 149.5 \mu \mathrm{g} / \mathrm{L})$ and $\mathrm{P} 2 \mathrm{C} 16(273.0 \pm 163.1 \mu \mathrm{g} / \mathrm{L})$, which also resulted in significant differences over time $(\mathrm{P}<0.01)$ (Fig. 1d). For the most part, the values were above the values recommended by Boyd (1998), that is, between 50 and $75 \mu \mathrm{g} / \mathrm{L}$.

Nutrient concentrations increased throughout the experiment. Ammonia levels were significantly different over time $(\mathrm{P}<0.01)$, but not among treatments $(\mathrm{p}=0.39)$, probably due to supplied feed and increased excretion by the animals. The lowest mean values 9.8 and $6.4 \mu \mathrm{g} / \mathrm{L}$ were observed for treatments $\mathrm{P} 2 \mathrm{C} 0$ and $\mathrm{P} 2 \mathrm{C} 04$, respectively, and the highest 39.1 and $50.6 \mu \mathrm{g} / \mathrm{L}$ for $\mathrm{P} 2 \mathrm{C} 08$ and $\mathrm{P} 2 \mathrm{C} 16$, respectively (Fig. 1e). These values were below the $1.0 \mathrm{mg} / \mathrm{L}$ value recommended by Boyd (1998). P-orthophosphate values increased from the second month, peaking in the fourth month. The concentrations were as follows 24.2 $\mu \mathrm{g} / \mathrm{L}$ (P2C0), 73.7 (P2C04), 58.8 (P2C08) and 17.4 (P2C16) (Fig. 1f). The concentrations remained below the maximum levels recommend by Boyd $(1998)<3000.0 \mu \mathrm{g} / \mathrm{L}$ for all treatments.

Stocking density of prawns did not affect significantly tilapia mean final weight among treatments $(\mathrm{p}=0.59)$. Tilapia mean final weight was $357.4 \mathrm{~g}$ (P2C0), 333.1g (P2C04), 331.4g (P2C08) and $361.5 \mathrm{~g}$ (P2C16) (Fig. 2a). Candido et al. (2005), while studying multi-trophic system of $O$. niloticus and $L$. vannamei during 120 days, reported the following tilapia mean final weights: $226.7 \mathrm{~g}, 220.4 \mathrm{~g}$ and $257.0 \mathrm{~g}$, for the stocking density of $2 \mathrm{fish} / \mathrm{m}^{2}$ and 4,8 and 12 prawns $/ \mathrm{m}^{2}$ respectively, with final weights below those reached in this study. Bessa-Júnior et al. (2012) also reported lower mean weights for 2 $\mathrm{fish} / \mathrm{m}^{2}$ density, $160.6 \mathrm{~g}, 164.8 \mathrm{~g}, 183.6 \mathrm{~g}, 161.5 \mathrm{~g}$ and $168.2 \mathrm{~g}$ for prawn stocking densities of 0,3 , 6,9 and $12 \mathrm{prawns} / \mathrm{m}^{2}$, respectively. The higher prawn biomass observed in this study is probably due to longer cultivation period, 150 days. Santos and Valenti (2002), while studying multitrophic cultivation of fish and prawns, also concluded that $M$. rosenbergii stocked at a density up to 6 individuals $/ \mathrm{m}^{2}$ does not affect Nile tilapia production reared at $1 \mathrm{fish} / \mathrm{m}^{2}$ density.

In the present study, M. amazonicum individual weight decreased as stocking density increased, that is, the higher the prawn density the lower the final weight. At the end of the experiment $\left(5^{\text {th }}\right.$ month), the mean individual weight of prawns was significantly higher for treatment $\mathrm{P} 2 \mathrm{C0} 4$ (4.4g) compared to treatments $\mathrm{P} 2 \mathrm{C} 08(3.4 \mathrm{~g})$ and P2C16 (3.0g) (Fig. 2b). This is most probably related to the fact that at higher stocking densities feed offer decreases due to intraspecific competition for food. Some studies have shown that in multi-tropic cultivation prawn development is more affected by their own stocking densities rather than fish stocking density (New, 1995). 

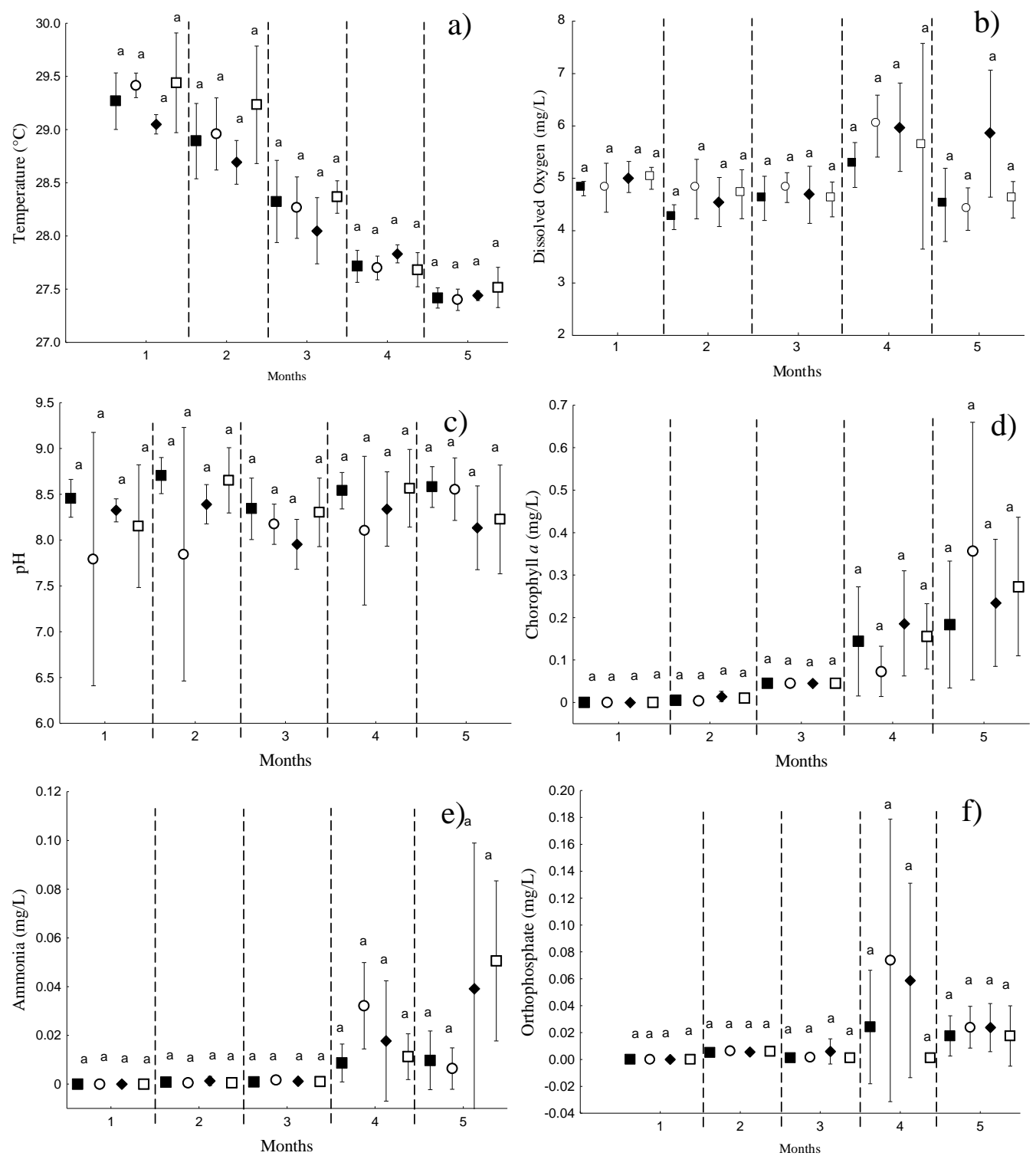

Figure 1. Mean values and standard deviation of a) temperature, b) dissolved oxygen, c) $\mathrm{pH}, \mathrm{d}$ ) chlorophyll "a", e) ammonia and f) orthophosphate for treatments along the five months of cultivation. The same letters indicate no significant differences by Tukey $(P<0.05)$. $\overline{1}_{\mathrm{P} 2 \mathrm{C} 0}$ 호 $\mathrm{P} 2 \mathrm{C} 04 \overline{\mathrm{P}} \mathrm{P} 08$ 도 $\mathrm{P} 2 \mathrm{C} 16$

Fish final survival rates were not significantly different among treatments (Tab. 1). Tilapia survival rate was not affected by prawn, since mean survival rate in the control treatment $\mathrm{P} 2 \mathrm{C} 0$ was similar to the survival rates observed in the multi-trophic cultivation. $O$. niloticus mean survival rates were higher than the values reported by García-Pérez et al. (2000), ranging between 84 and $85 \%$; Santos and Valenti (2002), between 64 and 72\%; and Bessa-Júnior et al. (2012), between 73 and $86 \%$. The high survival rates obtained in this study show that technical management was adequate and water physicochemical parameters were within the ideal range for the cultivation of the species. 

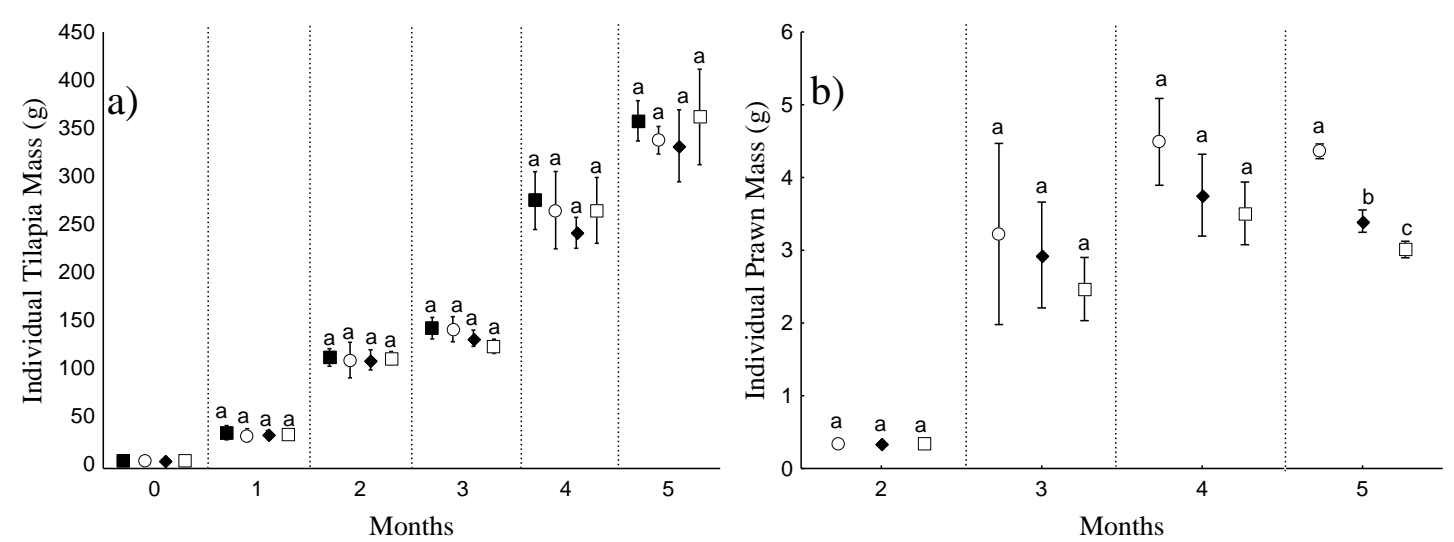

Figure 2. Mean values and standard deviation of individual weights of $O$. niloticus and M. amazonicum during cultivation period. Same letters mean no significant differences by Tukey $(P<0.05)$. 푸 P2C0 호

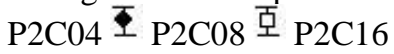

Table 1. Mean and standard deviation values for total biomass (kg/ha) and survival (\%) of O. niloticus and M. amazonicum in the different treatments. Different letters mean significant differences by Tukey $(P<0.05)$

\begin{tabular}{|c|c|c|c|c|c|c|c|c|}
\hline \multirow{2}{*}{ Variables } & \multicolumn{4}{|c|}{ Tilapia (O. niloticus) } & \multicolumn{4}{|c|}{ Prawn (M. amazonicum) } \\
\hline & $\mathrm{P} 2 \mathrm{CO}$ & $\mathrm{P} 2 \mathrm{C} 04$ & $\mathrm{P} 2 \mathrm{C} 08$ & $\mathrm{P} 2 \mathrm{C} 16$ & $\mathrm{P} 2 \mathrm{C} 0$ & $\mathrm{P} 2 \mathrm{C} 04$ & $\mathrm{P} 2 \mathrm{C} 08$ & $\mathrm{P} 2 \mathrm{C} 16$ \\
\hline Biomass & 6601.6(a) & 6137.4(a) & 5951.5(a) & $6531.2(\mathrm{a})$ & & $123.2(\mathrm{a})$ & $210.1(b)$ & $303.0(\mathrm{c})$ \\
\hline (Kg/ha) & \pm 479.5 & \pm 665.9 & \pm 648.7 & \pm 311.0 & - & \pm 15.5 & \pm 45.2 & \pm 16.8 \\
\hline Survival & $92.5(\mathrm{a})$ & $91.1(\mathrm{a})$ & $91.6(a)$ & 91.1(a) & & $65.6(a)$ & $77.3(\mathrm{a})$ & $61.5(a)$ \\
\hline$(\%)$ & \pm 7.4 & \pm 10.2 & \pm 4.3 & \pm 8.4 & - & \pm 7.9 & \pm 18.6 & \pm 2.5 \\
\hline
\end{tabular}

Final survival rates of prawn reared in polyculture treatments were also not significantly different (Tab. 1). However, unlike the high survival rates observed for tilapia, prawns had lower survival rates and these values are lower than the values reported by Candido et al. (2005) for a polyculture of $L$. vannamei and $O$. niloticus, where the mean survival rate values varied between $83.3 \%$ and $86.1 \%$; however, they are higher than the values reported by Bessa-Júnior et al. (2012), between $36 \%$ and $44 \%$ for $L$. vannamei.

Fish total biomass was not significantly different among treatments (Tab. 1). This fact supports the conclusion that prawn did not affect tilapia final yield. Santos and Valenti (2002) also concluded that the polyculture of prawn (M. rosenbergii) and tilapia did not affect fish production. However, these authors reported lower average yields with the following values $3445 \mathrm{~kg} / \mathrm{ha}$ for the control treatment (monoculture), and from 3671 to $3857 \mathrm{~kg} / \mathrm{ha}$ for tilapia in polyculture. The results of this study are also higher than the values reported by Bessa-Júnior et al. (2012), who reported average yield of $2701 \mathrm{~kg} / \mathrm{ha}$ for monoculture and values that varied from $2562 \mathrm{~kg} / \mathrm{ha}$ to $2814 \mathrm{~kg} / \mathrm{ha}$ for a polyculture.

Prawn total biomass (weight) increased as density also increased, with the following values $123.1 \mathrm{~kg} / \mathrm{ha}$ (P2C04); $210.1 \mathrm{~kg} / \mathrm{ha}(\mathrm{P} 2 \mathrm{C} 08)$ and $303.0 \mathrm{~kg} / \mathrm{ha}$ (P2C16) (Fig. 3). This indicates that system capacity was not achieved and prawns could have been stocked at higher density. It should be noted that there are currently no productive studies about multi-trophic cultivation of M. amazonicum. However, Moraes-Valenti and Valenti (2007) concluded that a monoculture of $M$. amazonicum can achieve average yield of $2051 \mathrm{~kg} / \mathrm{ha}$. With a similar cultivation method, Bessa-Júnior et al. (2012) reported that $L$. vannamei in polyculture with $O$. niloticus reached a yield of $383 \mathrm{~kg} / \mathrm{ha}$, higher than the values observed for $M$. amazonicum in this study.

The mean values of apparent feed conversion (AFC) for Nile Tilapia in the treatments suggested that prawn increasing density did not 
affect feed conversion (Fig. 3). Santos and Valenti (2002) reported higher feed conversion rates, with mean values of $1.94 ; 1.94$ and 1.86 for the treatments with 2,4 and 6 prawn postlarvae $/ \mathrm{m}^{2}$. Candido et al. (2005) observed mean feed conversion of $1.73,1.71$ and 1.47 for 4,8 and 12 prawns $/ \mathrm{m}^{2}$, respectively, while tilapia density remained 2 fish $/ \mathrm{m}^{2}$, AFC values were also higher than the values obtained in this study. The low feed conversion rates in this study may be related to the quality of the feed, which aimed to meet the nutritional requirements of Nile tilapia rather the Amazon River prawn.

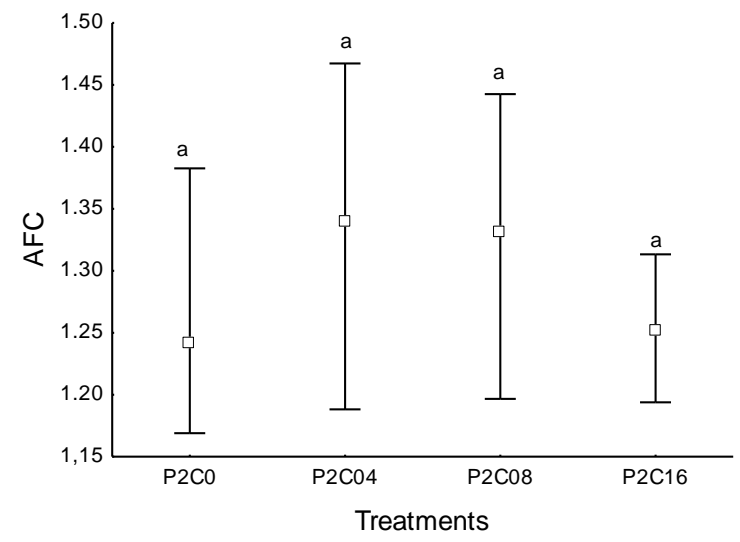

Figure 3. Mean values and standard deviation of apparent feed conversion for Nile tilapia in the different treatments. Different letters mean significant differences by Tukey $(\mathrm{P}<0.05)$. AFC $=$ Apparent Feed Conversion.

The average commercialization prices of the products are for 2011. These prices were observed or suggested by the local consumer market, consisting of individuals, supermarkets and restaurants. Prawn prices varied according to individual mean weight, that is, the price considered was US\$ $6.4 / \mathrm{kg}$ practiced for small shrimp, below $7 \mathrm{~g}$. Tilapias were considered in the market rank between 200 and $400 \mathrm{~g}$ at the selling price of US\$2.35/kg (Tab. 2).

Table 2. Variable (CVop), Fixed (CFop) and Total (CTop) operating costs and the relationship of cost per kilo of $O$. niloticus and M. amazonicum (US\$/Kg) produced in a multi-trophic system

\begin{tabular}{lllllll}
\hline Treatment & CVop & US\$/Kg & CFop & US\$/Kg & CTop & US\$/Kg \\
\hline P2C0 & US\$ 6,218.43 & 0.94 & US\$ 3,779.22 & 0.57 & US\$ 9,997.65 & 1.51 \\
P2C04 & US\$ 6,517.35 & 1.06 & US\$ 3,779.22 & 0.61 & US\$ 10,296.57 & 1.68 \\
P2C08 & US\$ 6,816.27 & 1.15 & US\$ 3,779.22 & 0.64 & US\$ 10,595.49 & 1.78 \\
P2C16 & US\$ 7,414.11 & 1.14 & US\$ 3,779.22 & 0.58 & US\$ 11,193.34 & 1.71 \\
\hline
\end{tabular}

Variable operating costs are different between polyculture and monoculture, especially regarding the costs of introducing the different amounts of prawn post-larvae in each treatment, which reflects on the total operating cost.

In the control treatment the monoculture (P2C0) gross revenue was US\$ $14,095.33$ and not significantly different from the values observed for the multi-trophic systems, US\$ 13,893.29 (P2C04), US\$ 14,607.18 (P2C08) and US\$ $15,886.30$ (P2C16). The operating profit values were also not significantly different among treatments, US\$ 4,097.89 (P2C0); US\$ 3,724.83
(P2C04); US\$ 4,396.02 (P2C08) and US\$ 5,461.62 (P2C16). These statistically similar values may be related to low productivity of prawns in relation to fish high productivity, adding a relatively low value to the multi-trophic systems.

Economic performance values were also statistically similar among treatments, $40.1 \%$ (P2C0), 36.7\% (P2C04), 41.2\% (P2C08) and $50.1 \%$ (P2C16), although it was noted that it tended to increase when considering only the mean values of multi-trophic systems (Tab. 3). 
Henry-Silva et al.

Table 3. Mean values and standard deviation for Gross Revenue, Operating profit and Economic Performance of treatments. Different letters mean significant differences by Tukey $(P<0.05)$

\begin{tabular}{lllll}
\hline Variables & P2C0 & P2C04 & P2C08 & P2C16 \\
\hline \multirow{2}{*}{ Revenue (US\$) } & $14,095.55(\mathrm{a})$ & $13,893.29(\mathrm{a})$ & $14,607.18(\mathrm{a})$ & $15,886.30(\mathrm{a})$ \\
& $\pm 1,023.75$ & $\pm 1,438.77$ & $\pm 1,514.25$ & \pm 696.27 \\
& & & & \\
Profit (US\$) & $4,097.89(\mathrm{a})$ & $3,724.83(\mathrm{a})$ & $4,396.02(\mathrm{a})$ & $5,461.62(\mathrm{a})$ \\
& $\pm 1,023.75$ & $\pm 1,471.82$ & $\pm 1,514.25$ & \pm 696.27 \\
Profitability (R\$) & $21.83(\mathrm{a})$ & $19.59(\mathrm{a})$ & $22.37(\mathrm{a})$ & $26.69(\mathrm{a})$ \\
& \pm 5.44 & \pm 7.85 & \pm 7.58 & \pm 3.74 \\
\hline
\end{tabular}

\section{CONCLUSIONS}

Different prawn stocking densities did not affect survival rates and total biomass gain of Nile tilapia. Final individual weight of prawns decreased as stocking density increased, the highest final weight was observed for the lowest density ( $\mathrm{P} 2 \mathrm{C} 04)$. The highest prawn productivity was observed for treatment $\mathrm{P} 2 \mathrm{C} 16$, due to the highest stocking density, although individual final weight was the lowest. The polyculture of $M$. amazonicum and $O$. niloticus did not change the profitability, thus proving to be technically and economically feasible.

\section{ACKNOWLEDGEMENTS}

Thanks are due to Dr. Felipe Ribeiro for allowing us to use the infrastructure to conduct the experiment and to $\mathrm{CNPq}$ for the financial support given to the first author, to DNOCS for supplying the M. amazonicum post-larvae and to Aquarium Aquicultura do Brasil for providing the $O$. niloticus fingerlings and the supplies for the experiment.

\section{REFERENCES}

ARAR, E.J. Determination of Chlorophyll a, b, c1 and c2, and Pheophytin a in marine and freshwater phytoplankton by spectrophotometry. EPA method 446.0. EPA, 1997.

ARAUJO, M.C.; VALENTI, W.C. Feeding habit of the Amazon river prawn Macrobrachium amazonicum larvae. Aquaculture, v.265, p.187-193, 2007.

BESSA-JÚNIOR, A.P.; AZEVEDO, C.M.S.B.; THÉPONTES, F.E.; HENRY-SILVA, G.G. Polyculture of Nile tilapia and shrimp in different stocking densities. Rev. Bras. Zootec., v.47, p.1561-1569, 2012.
BIALETZKI, A.; NAKATANI, K.; BAUMGARTNER, G.; BOND-BUCKUP, G. Occurrence of Macrobrachium amazonicum (Heller) (Decapoda, Palaemonidae) in Leopoldo's inlet (Ressaco do Leopoldo), upper Paraná river, Porto Rico, Paraná, Brazil. Rev. Bras. Zool., v.14, p.379-390, 1997.

BOYD, C.E. Water quality in ponds for aquaculture. Alabama: Auburn, 1990. 482p.

BOYD, C.E. Pond water aeration systems. Aquaculture Engineering, v.18, p.9-40, 1998.

BOYD, C.E. Guidelines for aquaculture effluent management at the farm-levels. Aquaculture, v.226, p.101-112, 2003.

BOYD, C.E.; TUCKER, C.S. Pond aquaculture water quality management. Norwell: Kluwer Academic Publishers, 1998. 700p.

CANDIDO, A.S.; MELO JÚNIOR, A.P.; COSTA, O.R. et al. Efeito de diferentes densidades na conversão alimentar da tilápia Oreochromis niloticus com o camarão marinho Litopenaeus vannamei em sistema de policultivo. Rev. Cienc. Agron., v.36, p.279-284, 2005.

CHOPIN, T.; BUSCHMANN, A.H.; HALLING, C. et al. Integrating seaweeds into marine aquaculture systems: A key toward sustainability. J. Phycol., v.37, p.975-986, 2001.

COHEN, D.; RA'ANAN, Z. The production of the freshwater prawn Macrobrachium rosenbergii in Israel. III. Density effect of all-male tilapia hybrids on prawn yield characters in polyculture. Aquaculture, v.35, p.57-71, 1983.

GARCÍA-PÉREZ, A.; ALSTON, D.E.; CORTÉZMALDONADO, R. Growth, survival, yield, and size distributions of freshwater prawn Macrobrachium rosenbergii and tilapia Oreochromis niloticus in polyculture and monoculture systems in Puerto Rico. J. World Aquacult. Soc., v.31, p.446-451, 2000. 
GOLTERMAN, H.L.; CLIMO, R.S.; OHNSTAD, M.A.M. Methods for physical and chemical analysis of fresh waters. 2.ed. Oxford: IBP, 1978. 213p.

KUTTY, M.N. Towards sustainable freshwater prawn. Aquaculture Res., v.36, p.255-263, 2005.

KUTTY, M.N.; HERMAN, F.; LE MENN, H. Culture of other prawn species. In: NEW, M.B.; VALENTI, W.C. (Eds). Freshwater prawn culture: The farming of Macrobrachium rosenbergii. Oxford: Blackwell Science, 2000. p.393-410.

LUTZ, C.G. Polyculture: principles, practices, problems, and promise. Aquaculture Magazine, v.5, p.34-39, 2003.

MACKERETH, F.J.H.; HERON, J.; TALLING, J.F. Water analysis: some revised methods for limnologists. London: Freshwater Biological Association, 1978. 121p.

MCGINTY, A.S.; ALSTON, D.E. Polyculture of allmale tilapia hybrids with low densities of Macrobrachium rosenbergii. J. Agricult. Univ. Puerto Rico, v.71, p.225-229, 1987.

MILSTEIN, A.; AHMED, A.F.; MASUD, O.A. et al. Effects of the filter feeder silver carp and the bottom feeders mrigal and common carp on small indigenous fish species (SIS) and pond ecology. Aquaculture, v.258, p.439-451, 2006

MORAES-RIODADES, P.M.C.; VALENTI, W.C. Freshwater prawn farming in Brazilian Amazonia shows potential for economic and social development. Global Aquaculture Advocade, v.4, p.73-74, 2001.

MORAES-VALENTI, P.; MORAES, P.A.; PRETO, B.L.; VALENTI, W.C. Effect of density on population development in the Amazon River prawn Macrobrachium amazonicum. Aquatic Biology, v.9, p.291-301, 2010.

MORAES-VALENTI, P.M.C.; VALENTI, W.C. Effect of Intensification on Grow Out of the Amazon River Prawn Macrobrachium amazonicum. J. the World Aquacult. Soc., v.38, p.516-526, 2007.
MUANGKEOW, B.; IKEJIMA, K.; POWTONGSOOK, S.; YI, Y. Effects of white shrimp, Litopenaeus vannamei (Boone), and Nile Tilapia, Oreochromis niloticus L., stocking density on growth, nutrient conversion rate and economic return in integrated closed recirculation system. Aquaculture, v.269, p.363-376, 2007.

NEW, M.B. Status of freshwater prawn farming: a review. Aquaculture Res., v.26, p.1-54, 1995.

NEW, M.B. Freshwater prawn farming: global status recent research and a glance at the future. Aquaculture Res., v.36, p.210-230, 2005.

NEW, M.B.; VALENTI, W.C.; TIDWELL, J.H. et al. (Eds). Freshwater prawns: biology and farming. Oxford: Wiley-Blackwell, 2010. 560p.

SAMPAIO, C.M.S.; SILVA, R.R.; SANTOS, J.A.; SALES, S.P. Reproductive cycle of Macrobrachium amazonicum females (Crustacea, Palaemonidae). Braz. J. Biol., v.67, p.551-559, 2007.

SANTOS, M.J.M.; VALENTI, W.C. Production of Nile Tilapia Oreochromis niloticus and freshwater Prawn Macrobrachium rosenbergii stocked at different densities in polyculture systems in Brazil. $J$. World Aquacult. Soc., v.33, p.369-376, 2002.

VALENTI, W.C. Cultivo de camarões de água doce. São Paulo: Nobel, 1985. 82p.

VALENTI, W.C.; KIMPARA, J.M.; PRETO, B.L. Measuring Aquaculture Sustainability. World Aquaculture, v.42, p.26-30, 2011.

WOHLFARTH, G.W.; HULATA, G.; KARPLUS, I.; HALEVY, A. Polyculture of the freshwater prawn Macrobrachium rosenbergii in intensively manured ponds and the effect of stocking rate of prawns and fish on their production characteristics. Aquaculture, v.46, p.142-56, 1985.

ZIMMERMANN, S.; NEW, M.B. Grow-out systems polyculture and integrated culture. In: NEW, M.B.; VALENTI, W.C. (Eds). Freshwater prawn farming: The farming of Macrobrachium rosenbergii. England: Blackwell Science, 2000. p.187-202. 